\title{
Aspect of Life Quality in Secondary Socialization: Experience of Learners' Parents
}

\author{
Vilija Grincevičienè ${ }^{1}$, Jonas Grincevičius ${ }^{2}$ \\ 1 Lithuanian University of Educational Sciences, Faculty of Social Education, Department of Social Work and \\ Sociology, Studentų St. 39, LT-08106 Vilnius, Lithuania, vilija.grinceviciene@leu.lt \\ 2 Lithuanian University of Health Sciences, Faculty of Pharmacy, Department of Drug Technology and Social \\ Pharmacy, Mickevičiaus St. 9, LT-44307 Kaunas, Lithuania, jonasgrin@gmail.com
}

\begin{abstract}
The article analyzes reflection of life quality in secondary socialization with reference to the experience of learners' parents. The research has revealed that every second respondent is satisfied with his / her life achievements; every third respondent has achieved everything he / she could in life; learners' parents tend to link their life quality primarily with health, financial status, successful marriage, profession, relationships with relatives and children's achievements.
\end{abstract}

Keywords: secondary socialization, life quality, health, period of adulthood; learners' parents, school.

\section{Introduction}

The fast changing social reality presupposes changes in individual relationships with social institutions, values, other members of the society and the person him / herself. Thus, we all constantly participate in the process of social interaction, which is determined by both biological and cultural context. Socialization is a life-long process, which involves not only activeness of a developing personality, but also the impact of social environment on it. Socialization may be defined as a social process of personality becoming, which is based on the interception of values, norms, attitudes and behaviour characteristic to one or another society, social community or group. There are two types of socialization distinguished: primary (in the childhood and adolescence) and secondary (in the 
adulthood). According to Berger and Luckmann (1999), secondary socialization is the internalization of 'subworlds' developed on the basis of institutions. In the process of secondary socialization, the internalized 'subworlds' normally involve partial reality, differently from the 'fundamental world', which is acquired through primary socialization.

In the process of secondary socialization (in the period of mature age), a person encounters the already developed $I$ and previously internalized norms, values and different experience. There is no unanimous agreement regarding the periods of human age. Different authors define age periods of an adult differently:

- Gučas (1990) distinguishes the primary stage of adulthood (22 males (21 females)-35) and secondary stage of adulthood (36-55 females (60 males);

- Levinson (1978) points out to the early period of adulthood (22-40) and the medial period of adulthood (40-60);

- B. P. Newman (1987) distinguishes between the period of a young adult (22-34) and the medial period of an adult (34-60).

Since there is no unanimous agreement regarding the periods of adult age, nor are the age limits clearly defined, learners' parents are attributed to the age group of adults (30-50 years of age) in this article. This is the space of secondary socialization, where a person contemplates on and accepts news roles (a father, a mother), participates in professional socialization, and frequently in different levels of resocialization. Upon the achievement of the said age, persons have already accumulated different experience; therefore, they can relatively realistically evaluate the quality of their life.

The problems of life quality have been analyzed by sociologists, educationalists, psychologists and researchers of biomedicine: L. Jovaiša (2009), G. Janušauskaitė (2008), G. Merkys et al. (2008), B. Gruževskis (2012), B. H. Lemme (2003), R. Havighurst (1953), and P. Berger, T. Luckmann (1999). Identification of the experience and assessment of own life quality by learners' parents should contribute to the exploration of the problem.

Object of the research: experience of learners' parents (foster parents) in terms of life quality.

Subject of the research: the assessment of own life quality of parents (foster parents) of comprehensive school learners.

Aim of the research: to reveal how learners' parents (foster parents) evaluate their life quality.

\section{Objectives of the research:}

1) to disclose how learners' parents (foster parents) value their personal achievements in life;

2) to identify factors determining life quality of parents raising school learners;

3) to reveal the place of education in secondary socialization. 


\section{Methodology}

The research is based on the paradigm (approach) of structural functionalism: a society is an integral social system composed of a number of elements, which perform a certain function; all the elements function strictly in terms of mutual interaction and develop a coherent system ensuring regular functioning of the whole organism;

Humanist theory of personal development (C. Rogers), which emphasizes human freedom, striving for self-realization and development of inborn capabilities; reference is made to C. Rogers' theory principles:

- there is opposition between two approaches: a human being directs him / herself to an aim and is able to actively achieve it versus human behaviour is dependent on uncontrollable power;

- a human being demonstrates positive behaviour provided his / her internal nature is not inhibited, i.e. s/he searches for harmony with oneself and others;

- a human being is inclined to move to social responsibility, creativity and maturity.

\section{Methods of the research:}

1. Theoretical: analysis of sociological, pedagogical, psychological and philosophical literature, normative acts regulating the system of education, and data on the process of education;

2. Comparative analysis of conceptions, approaches and attitudes;

3. Empirical: identification of the attitudes of learners' parents using questionnaires and letters.

\section{Research methodology}

A quantitative method was employed to collect primary empirical data. The research was conducted in the winter and spring of 2012. The research geography covered all regions of the country. The sample was selected as follows: learners' parents (foster parents) were 30-50-year-old citizens of Lithuania. Sample design was based on the analysis of the database of Statistics Department of the Republic of Lithuania and drawn with regard to age and gender. The scope of the sample (30-50-year-old citizens of Lithuania) was relatively equated to the general population. If the general sample population is 100.000 , the research sample should be $>$ or $=398$ (6). Since research results are applied not only to the research sample, but also to the whole population, its representativeness was ensured by designing a sample of 600 respondents. 


\section{Research sample.}

The research sample was designed aiming to achieve representativeness of the research. A deviation of 0.05 was chosen, which is standard in social sciences. The sampling was carried out following the 'snowball' principle. Firstly, respondents who raise children of school age were selected from different regions. They invited other parents to take part in the research, and these in turn invited others. Thus, the sample extended up to 600, out if which 502 questionnaires were returned.

The primary data was coded and statistically processed using SPSS 10.0 for Windows. Descriptive statistics was applied to analyze the obtained data.

Table 1. Information about respondents

\begin{tabular}{|c|c|c|}
\hline \multicolumn{2}{|r|}{ Characteristics } & $(\%)$ \\
\hline \multirow{2}{*}{ Sex } & Females & 87 \\
\hline & Males & 13 \\
\hline \multirow{3}{*}{ The age groups } & up to 40 years & 65 \\
\hline & $41-50$ years & 31 \\
\hline & $51-60$ years & 4 \\
\hline \multirow{4}{*}{ Levels of education } & secondary & 2 \\
\hline & Vocational & 16 \\
\hline & higher non-university & 44 \\
\hline & higher university & 38 \\
\hline \multirow{3}{*}{ Residence } & $\begin{array}{l}\text { In five large cities of the country: Vilnius, Kaunas, } \\
\text { Klaipeda, Šiauliai, Panevežys. }\end{array}$ & 78 \\
\hline & in towns (region centres) & 14 \\
\hline & in rural areas & 8 \\
\hline \multirow{7}{*}{ According to social groups } & housewives & 8 \\
\hline & $\begin{array}{l}\text { specialists of non-industrial profile (employed in } \\
\text { culture, education, welfare system, lawyers). }\end{array}$ & 13 \\
\hline & $\begin{array}{l}\text { specialists of industrial profile (engineers, tech- } \\
\text { nologists). }\end{array}$ & 13 \\
\hline & workers & 31 \\
\hline & Farmers & 1 \\
\hline & business people (having own business. & 14 \\
\hline & $\begin{array}{l}\text { civil servants (providers of different services, } \\
\text { freelancers }\end{array}$ & 20 \\
\hline
\end{tabular}


Methods of mathematical statistics confidence intervals were applied. If the reliability if $95 \%$, the interval then is:

$$
\left[\left(a-1,960 \sqrt{\frac{\mathrm{a}(1-\mathrm{a})}{m}} \% ;\left(a+1.960 \sqrt{\frac{\mathrm{a}(1-\mathrm{a})}{m}} \%\right]\right.\right.
$$

where $m$ - is the number of respondents (the sample);

$$
a=\frac{m_{\mathrm{A}}}{m} \bullet 100 \% \quad \text {-percentage of respondents possessing feature }(A) \text {; }
$$

$m_{\mathrm{A}}-$ number of respondents claiming to have feature (A).

\section{Research results}

A person accomplishes a number of functions in adulthood, among which the most significant are integration, control and self realization. The mentioned functions ensure satisfaction of a person's needs and interests, social adaptation and transfer of cultural values. However, every person is an individual. Therefore, their achievements in life, their conceptions and values are also individual. It is assumed that there is a direct dependence between an individual's satisfaction with personal achievements in life and the speed of positive socialization, and vice versa. The analysis of research results has revealed that learners' parents (foster parents) value personal achievements in life. It is of great significance, since the emotional environment created by parents directly affects both their children and other members of the family and close environment (See Table 2).

Table 2. Distribution of respondents in terms of attitudes towards satisfaction with personal achievements in life (\%)

\begin{tabular}{|l|c|}
\hline \multicolumn{1}{|c|}{ Statements } & $\begin{array}{c}\text { Percentage and confidence intervals with } \\
\mathbf{9 5 \%} \text { reliability }\end{array}$ \\
\hline Yes, I am satisfied & $51.6[47.2-56.0]$ \\
\hline I achieved everything I could, but I expected more & $20.0[16.5-23.5]$ \\
\hline I achieved everything I could, though I expected less & $8.1[50.7-10.5]$ \\
\hline I am dissatisfied, I achieved less than I expected & $14.7[11.6-17.8]$ \\
\hline No answers provided & $5.6[3.6-7.6]$ \\
\hline
\end{tabular}

The age of adulthood is considered a period of biological and psychological balance, and culmination of creative activity. Every second respondent claimed that they were 
satisfied with their life achievements, and almost every third parent stated having achieved everything they could. These responses reflect the ability of the most productive part of the society to successfully solve tasks related to adult development. It is assumed that respondents, who were dissatisfied with their achievements $(14.7 \%)$ or did not provide their answers (5.6\%), faced challenges of the epoch and experienced difficulties or hardship. Behaviour in analogous situations is also individual: overworking is a one of the preconditions of frustration in both primary and secondary socialization.

According to Havighurst (1953), a major task of development is the most significant achievement, which is expected to be achieved by a person at a certain life period. Help for the children to become responsible and happy is one of the tasks, solved by parents when communicating and collaborating with the school. The research revealed that respondents, who were satisfied with their achievements in life, established closer cooperation with the school rather than parents, whose expectations had not been fulfilled. The fact that every second parent (foster parent) visited the school only during parents' meetings revealed not only problems in parent-school interaction, but also a person's passiveness, i.e. inclination to avoid new social experiences (See Table 3).

Table 3. Relationship between the achievements of learners' parents and partnership with the school (\%)

\begin{tabular}{|l|c|c|c|c|c|c|}
\hline \multirow{2}{*}{$\begin{array}{c}\text { How do you assess } \\
\text { your cooperation with } \\
\text { the school? }\end{array}$} & $\begin{array}{c}\text { Yes, I am } \\
\text { satisfied }\end{array}$ & $\begin{array}{c}\text { Are you satisfied with your achievements in life? } \\
\text { everything } \\
\text { I could, but } \\
\text { I expected } \\
\text { more }\end{array}$ & $\begin{array}{c}\text { I achieved } \\
\text { everything } \\
\text { I could, tho- } \\
\text { ugh I expec- } \\
\text { ted less }\end{array}$ & $\begin{array}{c}\text { I am dis- } \\
\text { satisfied, I } \\
\text { achieved } \\
\text { less than I } \\
\text { expected }\end{array}$ & $\begin{array}{c}\text { No answers } \\
\text { provided }\end{array}$ & Total \\
\hline No answer provided & 1 & 2 & 1 & 1 & - & 5 \\
\hline $\begin{array}{l}\text { I have no contacts with } \\
\text { the school and do not } \\
\text { want to establish them }\end{array}$ & 2 & 3 & - & 2 & - & 7 \\
\hline $\begin{array}{l}\text { I visit the school only } \\
\text { when there is a need }\end{array}$ & 59 & 12 & 7 & 5 & - & 83 \\
\hline $\begin{array}{l}\text { I visit the school only } \\
\text { during parents' mee- } \\
\text { tings }\end{array}$ & 146 & 50 & 12 & 49 & 10 & 267 \\
\hline $\begin{array}{l}\text { I frequently commu- } \\
\text { nicate with school } \\
\text { teachers }\end{array}$ & 51 & 33 & 21 & 17 & 18 & 140 \\
\hline Total & 259 & 100 & 41 & 74 & 28 & 502 \\
\hline
\end{tabular}

The principle of a person's activity permits better understanding of the nature and essence of the term socialization, which may be defined as a process of interaction between 
an individual and a society, based on an individual's objective-restructuring activity. The results of such activity is a new specific social experience of an individual. When being actively involved in the processes of school change (communicating with teachers and social partners), learners' parents (foster parents) cumulate new experiences, which largely presuppose development of a person's overall self-respect. An individual's assessment of own achievements in life depends on his / her self-respect: the sense of personal value is essential to every person and is his / her basic need.

Table 4. Distribution of respondents' attitude towards factors determining their life quality (\%)

\begin{tabular}{|l|c|}
\hline \multicolumn{1}{|c|}{ The quality of life is determined by: first place } & $\begin{array}{c}\text { Percentage and confidence intervals with } \\
\mathbf{9 5 \%} \text { reliability }\end{array}$ \\
\hline health & $54.7[50.4-59.2]$ \\
\hline financial position & $15.9[12.7-19.1]$ \\
\hline successful marriage & $11.2[8.4-14.0]$ \\
\hline profession & $9.6[7.0-12.2]$ \\
\hline relationships with the family & $8.6[6.1-11.1]$ \\
\hline relationships with the family & $18.3[14.9-21.7]$ \\
\hline financial position & $17.9[14.5-21.3]$ \\
\hline health & $15.7[12.5-18.9]$ \\
\hline profession & $15.7[12.5-18.9]$ \\
\hline successful marriage & $14.1[11.1-17.1]$ \\
\hline relationships with colleagues & $8.2[5.8-10.6]$ \\
\hline spiritual beauty & $7.6[5.3-9.9]$ \\
\hline living place & $2.0[0.8-3.2]$ \\
\hline children's achievements & $0.5[0.1-1.1]$ \\
\hline relationships with the family & $31.0[27.0-35.0]$ \\
\hline children's achievements & $16.4[13.2-19.6]$ \\
\hline health & $10.0[7.4-12.6]$ \\
\hline successful marriage & $9.8[7.2-12.4]$ \\
\hline profession & $7.6[5.3-9.9]$ \\
\hline physical beauty & $7.2[4.9-9.5]$ \\
\hline financial position & $6.4[4.3-8.5]$ \\
\hline spiritual beauty & $5.8[3.8-7.8]$ \\
\hline living place & $3.6[2.0-5.2]$ \\
\hline relationships with colleagues & $2.2[0.9-3.5]$ \\
\hline
\end{tabular}

It is assumed that if learners' parents (foster parents) were involved into the modelling and organization of educational process, the school would attract more attention from 
the society: the status of the school and teacher's professional would increase, social, pedagogical and psychological problems would be solved more easily, as well as appropriate quality of education would be ensured. Therefore, teacher-parent partnership can be assumed as one of the preconditions for both social adaptation and social interiorization.

The research revealed links among a respondent's age, gender, education and interaction with the school. Women tend to communicate with the school closer than men; young parent (up to 40) visit schools more often than older parents; the contacts of respondents having higher non-university or higher university education are more frequent and closer than of the parents having secondary or vocational education. The analysis of research data helped to identify factors, which were most significant for parents to achieve their goals, i.e. significantly determined and still determine their life quality. Respondents divided the factors according to their significance by placing health, financial position, successful marriage, profession and relationships with the family at first place (See Table 4).

The second and third places were attributed to the relationships with the family by research participants. Cordial relationships presuppose a positive emotional environment, which is considered the main fundamental of both mental and physical health under the conditions of rapid changes in the society. When assessing their life quality, respondents ranked financial position and children's achievements quite high: there is a direct dependence of a family's financial position and support for children to acquire a desired profession correspondingly affect the socialization process of both children and parents. The latter situation also partly defines the environment of family relationships.

The research revealed respondents' attitude towards the impact of education on life quality. Data analysis permitted identification of the distribution of the attitudes of learners' parents towards the relationship between higher education and life quality: a greater part of respondents (80\%) claimed that higher education definitely / probably improved their life quality. Respondents, who expressed doubts and / or thought that there was no links between life quality and higher education, constituted a minority. Only $4 \%$ of research participants provided no answers regarding the impact of higher education on life quality, which shows the society's attitude towards education as a value (See Table 5).

Table 5. Distribution of respondents' attitudes towards impact of higher education on their life quality (\%)

\begin{tabular}{|l|c|}
\hline \multicolumn{1}{|c|}{ Statements } & $\begin{array}{c}\text { Percentage and confidence intervals with 95\% reliabi- } \\
\text { lity }\end{array}$ \\
\hline I agree & $42.4[38.1-46.7]$ \\
\hline I agree rather than disagree & $35.9[31.7-40.1]$ \\
\hline I disagree rather than agree & $12.7[9.8-15.6]$ \\
\hline I disagree & $5.0[3.1-6.9]$ \\
\hline No answers provided & $4.0[2.3-5.7]$ \\
\hline
\end{tabular}


The links between respondents' education and interaction with the school revealed that parents' (foster parents') education may be perceived as a factor enhancing family-school partnership: parents having higher non-university or higher university education communicated with teachers more often and vice versa. It is noteworthy that there was not a single parent having secondary education, who communicated closely with the teachers (school) (See Table 6).

Table 6. Links between parents' (foster parents') education and partnership with the school (\%)

\begin{tabular}{|c|c|c|c|c|c|}
\hline \multirow[b]{2}{*}{$\begin{array}{l}\text { How do you assess your communication } \\
\text { with the school? }\end{array}$} & \multicolumn{4}{|c|}{ Education of respondents } & \multirow[b]{2}{*}{ Total } \\
\hline & Secondary & $\begin{array}{l}\text { Professio- } \\
\text { nal }\end{array}$ & $\begin{array}{l}\text { Higher } \\
\text { non-uni- } \\
\text { versity }\end{array}$ & $\begin{array}{l}\text { Higher } \\
\text { university }\end{array}$ & \\
\hline No answers provided & - & - & 4 & 1 & 5 \\
\hline $\begin{array}{l}\text { I have no contacts with the school and do } \\
\text { not want to establish them }\end{array}$ & 1 & - & 5 & 1 & 7 \\
\hline I visit the school only when there is a need & 7 & 34 & 35 & 7 & 83 \\
\hline $\begin{array}{l}\text { I visit the school only during parents' } \\
\text { meetings }\end{array}$ & 3 & 37 & 117 & 110 & 267 \\
\hline $\begin{array}{l}\text { I frequently communicate with school } \\
\text { teachers }\end{array}$ & - & 11 & 62 & 67 & 140 \\
\hline Total & 11 & 82 & 223 & 186 & 502 \\
\hline
\end{tabular}

The relationships of parents having secondary or vocational education with the school were rather episodic: during parents' meetings or when there was a necessity. Having analyzed the research data, it appeared that this group of respondents was not satisfied with the quality of communication with their children. Hence, parents' education may be considered as a factor creating positive relationships between parents and children.

\section{Conclusions}

1. Socialization is a life-long process. Learners' parents, as objects of social relationships, experience the effect of social environment, whereas as subjects of social relationships, they change the social environment themselves. Learners' parents are adult people (30-50-year-old), but have a rather different social status and represent different professions; the fact that every second respondent was satisfied with their achievements in life, and every third achieved everything they could, argues for the coherence of the process of secondary socialization, stability of a society and a person's ability to successfully solve tasks related to the development of an adult. 
2. Social roles of a father / mother turn secondary socialization in a particular direction: the roles may become part of a personality when a person identifies him / herself with them. Learners' parents are inclined to link their life quality primarily with health, financial position, successful marriage, profession, relationships with the family and children's achievements.

3. The role of education as value is significant in secondary socialization: a greater part of respondents $(80 \%)$ claimed that higher education definitely / probably improved their life quality; education of learners' parents is considered as a factor determining positive parent-child relationships ad developing school-family interaction based on partnership principles.

\section{References}

Berger, P., Luckmann, T. (1999). Socialinès tikrovès konstravimas: žinojimo sociologijos traktatas. Vilnius: Pradai.

Gruževskis, B., Orlova, U. L. (2012). Sąvokos „gyvenimo kokybe“ raidos tendencijos. Socialinis darbas, 11 (1), 7-18.

Havinghurst, R. (1953). Human Development and Education. New York: Longmans, Green. Janušauskaite, G. (2008). Gyvenimo kokybės tyrimai: problemos ir galimybès. Filosofija Sociologija. 19 (4), 34-44.

Jovaiša, L. (2009). Gyvenimo sèkmès ugdymas. Vilnius: Agora.

Kardelis, K. ( 2007). Moksliniu tyrimų metodologija ir metodai. Šiauliai: Liucijus.

Merkys, G., Brazienè, R., Kondrotaitė, G. (2008). Subjektyvi gyvenimo kokybė kaip socialinis indikatorius: viešojo sektoriaus kontekstas. Viešoji politika ir administravimas, 23, 23-38.

Lemme, B. H. (2003). Suaugusiojo raida. Kaunas: Poligrafija ir informatika. 


\title{
Gyvenimo kokybès aspektas antrinès socializacijos erdvèje: mokinių tèvų patirtys
}

\author{
Vilija Grincevičiene $\dot{e}^{1}$, Jonas Grincevičius ${ }^{2}$
}

1 Lietuvos edukologijos universitetas, Socialinès edukacijos fakultetas, Socialinio darbo ir sociologijos katedra, Studentų g. 39, 08106 Vilnius, vilija.grinceviciene@leu.lt

2 Lietuvos sveikatos mokslų universitetas, Farmacijos fakultetas, Vaistų technologijos ir socialinės farmacijos katedra, A. Mickevičiaus g. 9, 44307 Kaunas, jonasgrin@gmail.com

\section{Santrauka}

Straipsnyje, remiantis mokinių tèvų patirtimi, analizuojama, kaip antrinės socializacijos erdveje atsispindi gyvenimo kokybès aspektas. Tyrimas atliktas $2012 \mathrm{~m}$. žiemąpavasarị. Tyrimo geografija - visi šalies regionai. Imties tūris - 502. Tyrimo objektas: mokinių tèvų (globejjų) patirtys gyvenimo kokybès aspektu. Tyrimo dalykas: bendrojo lavinimo mokykloje besimokančių mokinių tèvų (globejjų) savo gyvenimo kokybès vertinimai. Tyrimo tikslas - atskleisti, kaip mokinių tèvai (globejjai) vertina savo gyvenimo kokybę. Tyrimo uždaviniai: 1 ) atskleisti, kaip mokinių tèvai (globẻjai) vertina asmeninius pasiekimus gyvenime; 2) identifikuoti veiksnius, ryškiausiai lėmusius tėvų, auginančių mokyklinio amžiaus vaikus, gyvenimo kokybę; 3) atskleisti išsimokslinimo vietą individo antrinès socializacijos erdveje. Tyrimu atskleista, kad kas antras respondentas yra patenkintas savo pasiekimais gyvenime, beveik kas trečias - pasiekęs tai, ką galèjo pasiekti; mokinių tèvai, savo gyvenimo kokybę visų pirma linkę sieti su sveikata, materialine padetimi, sèkminga santuoka, profesija, santykiais su artimaisiais bei vaiku pasiekimais. Antrinès socializacijos erdvejje svarbus išsimokslinimo / išsilavinimo kaip vertybès vaidmuo: didžioji dalis respondentų ( $\sim 0$ proc.) nurodè, kad aukštesnis išsimokslinimas tikrai (tikriausiai) galètų pagerinti jų gyvenimo kokybę.

Esminiai žodžiai: antrine socializacija, gyvenimo kokybe, sveikata, suaugusiojo amžiaus tarpsnis, mokiniu tèvai, mokykla. 